\title{
Severe Hypocalcemia after Renal Transplantation: An Extreme Case of Hungry Bone Syndrome
}

\author{
Samia Elkarci ${ }^{1 *}$, Mariam Chettati ${ }^{1}$, Wafaa Fadili ${ }^{1}$, Inass Laouad ${ }^{1}$
}

${ }^{1}$ Nephrology-Hemodialysis-Transplantation Departement, Arrazi hospital, University hospital Mohammed VI, Marrakech, Morocco

DOI: $\underline{10.36347 / \mathrm{simcr} .2022 . v 10 \mathrm{i} 01.002}$

| Received: 02.12.2021 | Accepted: 06.01.2022 | Published: 10.01.2022

*Corresponding author: Samia Elkarci

Nephrology-Hemodialysis-Transplantation Departement, Arrazi hospital, University hospital Mohammed VI, Marrakech, Morocco

\section{Abstract}

Hungry bone syndrome is a rare but potentially lethal complication that is characterized by rapid, severe, long-lasting hypocalcemia and hypophosphatemia secondary to increased bone metabolism. Hereby, we present a case of a 38 year-old patient who received a kidney transplant 09 months after a subtotal parathyroidectomy. She developed severe hypocalcemia and hypophosphatemia 15 days after renal transplant and required high-dose of calcium for 4 months thereafter. The aim of this case report is to highlight and raise awareness for the importance of strict nutritional and electrolyte management in the post transplantation period. A prompt diagnosis and correction of hungry bone syndrome are imperative to prevent the associated significant morbidity and mortality [1].

Keywords: Hungry bone syndrome; hypocalcemia; parathyroidectomy; renal transplantation.

Copyright $($ C) 2022 The Author(s): This is an open-access article distributed under the terms of the Creative Commons Attribution 4.0 International License (CC BY-NC 4.0) which permits unrestricted use, distribution, and reproduction in any medium for non-commercial use provided the original author and source are credited.

\section{INTRODUCTION}

The Hungry Bone Syndrome (HBS) is defined by persistent hypocalcemia for several days after the collapse of PTH levels, through an active bone remineralization process. It is a complication of parathyroidectomy performed in primary hyperparathyroidism, or autonomous in renal failure.

HBS can be observed minimally after renal transplantation [2]. We describe here an extreme case of HBS in the aftermath of renal transplantation.

\section{Case Presentation}

A 38-year-old female, chronic hemodialysis since 2008, who received a kidney transplant from a related living donor (her mother) 09 months after a subtotal parathyroidectomy (diffuse hyperplasia). On the day of transplantation, corrected $\mathrm{Ca}=87 \mathrm{mg} / \mathrm{l}$ and $\mathrm{PTH}=29 \mathrm{ng} / \mathrm{ml}(\mathrm{n}=15-65 \mathrm{pg} / \mathrm{ml})$ with normal $25-\mathrm{OH}$ D3 levels. The evolution was marked by an immediate recovery of the renal function with a creatinine level at $9 \mathrm{mg} / \mathrm{l}$ at the tenth day

She consulted on day 15 of the transplantation for cramps, tremors, spasms of the face and the neck. the biological check-up finds : Corrected serum calcium level at $56 \mathrm{mg} / \mathrm{L}$, inappropriate parathyroid hormone level $=35 \mathrm{pg} / \mathrm{mL}$, transient hypophosphatemia was
$18 \mathrm{mg} / \mathrm{L}$. Bone anabolism markers are discreetly elevated (bone alkaline phosphatase at $107 \mathrm{mg} / \mathrm{l}$ ).

The correction of hypocalcemia had required intravenous calcium combined with high doses of oral calcium ( $12 \mathrm{~g}$ per day) for more than a month. Calcium was stopped progressively and suspended four months after renal transplantation.

\section{Discussion/CONCLUSION}

The conjunction over time of two etiologies of HBS, parathyroidectomy and renal transplantation, resulted in profound and symptomatic hypocalcemia requiring massive doses of IV calcium in addition to prolonged oral calcium and active vitamin $\mathrm{D}$ intakes. Close monitoring of serum calcium and calciuria should be performed following renal transplantation after a recent parathyroidectomy [3].

\section{REFERENCE}

1. Witteveen, J. E., Van Thiel, S., Romijn, J. A., \& Hamdy, N. A. (2013). Hungry bone syndrome: still a challenge in the post-operative management of primary hyperparathyroidism: a systematic review of the literature. Eur J Endocrinol, 168(3), R45-53.

2. Copley, J. B., \& Wüthrich, R. P. (2011). Therapeutic management of post-kidney transplant 
hyperparathyroidism. Clinical

transplantation, 25(1), 24-39.

3. Evenepoel, P., Claes, K., Kuypers, D., Maes, B., Bammens, B., \& Vanrenterghem, Y. (2004).
Natural history of parathyroid function and calcium metabolism after kidney transplantation: a singlecentre study. Nephrology Dialysis Transplantation, 19(5), 1281-1287. 